\title{
Front Matter: Volume 10854
}

, "Front Matter: Volume 10854," Proc. SPIE 10854, Endoscopic Microscopy XIV, 1085401 (17 May 2019); doi: 10.1117/12.2531187

SPIE. Event: SPIE BiOS, 2019, San Francisco, California, United States 


\title{
PROGRESS IN BIOMEDICAL OPTICS AND IMAGING
}

\section{Endoscopic Microscopy XIV}

\author{
Guillermo J. Tearney \\ Thomas D. Wang \\ Melissa J. Suter \\ Editors
}

2-4 February 2019

San Francisco, California, United States

Sponsored and Published by

SPIE 
The papers in this volume were part of the technical conference cited on the cover and title page. Papers were selected and subject to review by the editors and conference program committee. Some conference presentations may not be available for publication. Additional papers and presentation recordings may be available online in the SPIE Digital Library at SPIEDigitallibrary.org.

The papers reflect the work and thoughts of the authors and are published herein as submitted. The publisher is not responsible for the validity of the information or for any outcomes resulting from reliance thereon.

Please use the following format to cite material from these proceedings:

Author(s), "Title of Paper," in Endoscopic Microscopy XIV, edited by Guillermo J. Tearney, Thomas D. Wang, Melissa J. Suter, Proceedings of SPIE Vol. 10854 (SPIE, Bellingham, WA, 2019) Sevendigit Article CID Number.

ISSN: 1605-7422

ISSN: $2410-9045$ (electronic)

ISBN: 9781510623507

ISBN: 9781510623514 (electronic)

Published by

SPIE

P.O. Box 10, Bellingham, Washington 98227-0010 USA

Telephone +1360 676 3290 (Pacific Time) · Fax +1 3606471445

SPIE.org

Copyright @ 2019, Society of Photo-Optical Instrumentation Engineers.

Copying of material in this book for internal or personal use, or for the internal or personal use of specific clients, beyond the fair use provisions granted by the U.S. Copyright Law is authorized by SPIE subject to payment of copying fees. The Transactional Reporting Service base fee for this volume is $\$ 18.00$ per article (or portion thereof), which should be paid directly to the Copyright Clearance Center (CCC), 222 Rosewood Drive, Danvers, MA 01923. Payment may also be made electronically through CCC Online at copyright.com. Other copying for republication, resale, advertising or promotion, or any form of systematic or multiple reproduction of any material in this book is prohibited except with permission in writing from the publisher. The CCC fee code is 1605$7422 / 19 / \$ 18.00$.

Printed in the United States of America by Curran Associates, Inc. under license from SPIE.

Publication of record for individual papers is online in the SPIE Digital Library.

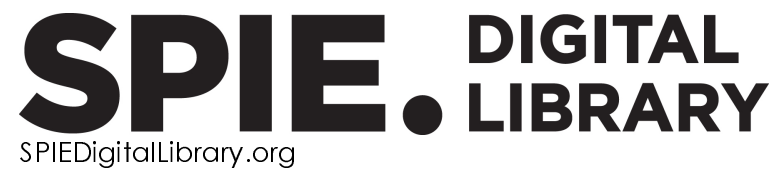

Paper Numbering: Proceedings of SPIE follow an e-First publication model. A unique citation identifier (CID) number is assigned to each article at the time of publication. Utilization of CIDs allows articles to be fully citable as soon as they are published online, and connects the same identifier to all online and print versions of the publication. SPIE uses a seven-digit CID article numbering system structured as follows:

- The first five digits correspond to the SPIE volume number.

- The last two digits indicate publication order within the volume using a Base 36 numbering system employing both numerals and letters. These two-number sets start with $00,01,02,03,04$, 05, 06, 07, 08, 09, OA, OB ... 0Z, followed by 10-1Z, 20-2Z, etc. The CID Number appears on each page of the manuscript. 


\title{
Contents
}

\author{
$\checkmark \quad$ Authors \\ vii Conference Committee
}

NEW ENDOMICROSCOPY TECHNIQUES

108516 A computational imaging approach for resolution enhancement in fiber bundle endomicroscopy [10854-43]

1085417 Towards high speed needle microscopy through a multimode fiber by single pixel imaging [10854-44]

ENDOSCOPIC MICROSCOPY: JOINT SESSION WITH CONFERENCE 10854 AND CONFERENCE 10931

10854 1D Motion compensation in structured illumination fluorescence endomicroscopy [10854-50]

POSTER SESSION

$10854 \mathrm{lE} \quad$ In vivo monitoring of theranostic fluorescence bacteria in orthotopic colon cancer model with multiscale fluorescence endoscopy [10854-38] 
Proc. of SPIE Vol. 10854 1085401-4

Downloaded From: https://www.spiedigitallibrary.org/conference-proceedings-of-spie on 26 Apr 2023 Terms of Use: https://www.spiedigitallibrary.org/terms-of-use 


\section{Authors}

Numbers in the index correspond to the last two digits of the seven-digit citation identifier (CID) article numbering system used in Proceedings of SPIE. The first five digits reflect the volume number. Base 36 numbering is employed for the last two digits and indicates the order of articles within the volume. Numbers start with 00, 01, 02, 03, 04, 05, 06, 07, 08, 09, OA, OB...0Z, followed by 10-1Z, 20-2Z, etc.

Bajwa, Waheed U., 16

Dumas, John P., 16

Hughes, Michael R., 17, 1D

Kim, Hyeon-Sik, 1E

Lee, Changho, $1 \mathrm{E}$

Lodhi, Muhammad A., 16

Mididoddi, Chaitanya K., 17

Min, Jung-Joon, $1 \mathrm{E}$

Pierce, Mark C., 16

Taki, Batoul A., 16

Thrapp, Andrew, 1D

Yoo, Su Woong, $1 \mathrm{E}$ 
Proc. of SPIE Vol. 10854 1085401-6

Downloaded From: https://www.spiedigitallibrary.org/conference-proceedings-of-spie on 26 Apr 2023 Terms of Use: https://www.spiedigitallibrary.org/terms-of-use 


\section{Conference Committee}

Symposium Chairs

James G. Fujimoto, Massachusetts Institute of Technology (United States)

R. Rox Anderson, Wellman Center for Photomedicine, Massachusetts General Hospital (United States) and Harvard Medical School (United States)

Symposium Co-chairs

Jennifer K. Barton, The University of Arizona (United States)

Wolfgang Drexler, Medical University of Vienna (Austria)

Program Track Chairs

Brian Jet-Fei Wong, Beckman Laser Institute and Medical Clinic, University of California, Irvine (United States)

Eva Sevick, The University of Texas Health Science Center at Houston (United States)

Conference Chairs

Guillermo J. Tearney, Wellman Center for Photomedicine (United States)

Thomas D. Wang, University of Michigan (United States)

Melissa J. Suter, Massachusetts General Hospital (United States)

Conference Program Committee

Matthew Brenner, University of California, Irvine (United States)

David L. Dickensheets, Montana State University (United States)

Arthur F. Gmitro, The University of Arizona (United States)

Lida P. Hariri, Massachusetts General Hospital (United States)

Ralf Kiesslich, Johannes Gutenberg Universität Mainz (Germany)

Francois Lacombe, Mauna Kea Technologies (France)

Stephen Lam, The BC Cancer Agency Research Center (Canada)

Hiroshi Mashimo, VA Boston Healthcare System (United States)

Kenzi Murakami, Olympus Corporation (Japan)

Norman S. Nishioka, Massachusetts General Hospital (United States)

Wibool Piyawattanametha, King Mongkut's Institute of Technology Ladkrabang (Thailand) 
Mark J. Schnitzer, Stanford University School of Medicine (United States)

Peter T. C. So, Massachusetts Institute of Technology (United States)

\section{Session Chairs}

1 Pathologist-Led Translation of Endomicroscopy Technologies: Joint Session between College of American Pathologists (CAP) and SPIE Guillermo J. Tearney, Wellman Center for Photomedicine (United States)

Lida P. Hariri, Massachusetts General Hospital (United States)

Maria M. Shevchuk, Weill Cornell Medicine (United States)

2 Endoscopic OCT

Melissa J. Suter, Massachusetts General Hospital (United States)

Matthew Brenner, University of California, Irvine (United States)

3 Multimodality Imaging

Johannes F. de Boer, Vrije University Amsterdam (Netherlands)

4 Advances in $\mathrm{E}-\mathrm{OCT}$

Robert A. McLaughlin, The University of Adelaide (Australia)

Michalina J. Gora, Laboratoire des Sciences de l'Ingénieur, de I'Informatique et de l'Imagerie (France)

5 OCT Contrast, Resolution, Function

David C. Adams, Massachusetts General Hospital (United States)

6 SEE+CLE

Dvir Yelin, Technion-Israel Institute of Technology (Israel)

DongKyun Kang, College of Optical Sciences, The University of Arizona (United States)

7 Fluorescence

Eric J. Seibel, University of Washington (United States)

8 New Endomicroscopy Techniques

DongKyun Kang, College of Optical Sciences, The University of Arizona (United States)

9 Endoscopic Microscopy: Joint Session with Conference 10854 and Conference 10931

Wibool Piyawattanametha, King Mongkut's Institute of Technology Ladkrabang (Thailand) 